\title{
KEDUDUKAN HUKUM AKTA JAMINAN FIDUSIA YANG TIDAK DIDAFTARKAN
}

\author{
Fince Ferdelina Huru \\ Magister Kenotariatan, Fakultas Hukum, Universitas Narotama Surabaya \\ Email: fincehuruasek1@gmail.com
}

\begin{abstract}
ABSTRAK
Salah satu keistimewaan dari pada jaminan fidusia tersebut adalah sifat eksekutorial jaminan fidusia pada sertifikat jaminan fidusia. Untuk memperoleh hak-hak tersebut maka jaminan tersebut wajib untuk didaftarkan pada Kantor Pendaftaran Jaminan Fidusia. Namun dalam pelaksanaannya, masih banyak jaminan fidusia yang tidak didaftarkan pada Kantor Pendaftaran fidusia. Penelitian ini menganalisis akibat hukum terhadap Jaminan fidusia yang tidak didaftarkan dan perlindungan hukum kepada kreditor jika akta Fidusia tidak didaftarkan. Metode penelitian yang digunakan adalah penelitian hukum normatif, yaitu penelitian hukum yang dilakukan dengan cara meneliti bahan pustaka atau bahan hukum sekunder sedangkan pendekatan masalah dilakukan dengan menggunakan pendekatan undang-undang dan pendekatan konseptual. Hasil penelitian menunjukkan bahwa akibat hukum terhadap akta jaminan fidusia yaitu tidak mempunyai kekuatan hukum sama sekali dalam melakukan eksekusi dan terhadap objek jaminan fidusia tidak melahirkan hak-hak kebendaan yang melekat pada jaminan fidusia. Sebagai akibat dari tidak didaftarkannya akta jaminan fidusia maka tidak ada perlindungan hukum sama sekali terhadap kreditor
\end{abstract}

Kata kunci: Perlindungan Hukum, Pendaftaran Akta Jaminan Fidusia, Eksekusi

\section{ABSTRACT}

One of the features of the fiduciary guarantee is the executorial nature of the fiduciary guarantee on the fiduciary guarantee certificate. To obtain these rights, the guarantee must be registered with the Fiduciary Guarantee Registration Office. But in its implementation, there are still many fiduciary guarantees that are not registered with the Fiduciary Registration Office. This study analyzes the legal consequences of fiduciary guarantees that are not registered and legal protection to creditors if the Fiduciary deed is not registered. The research method used is normative legal research, namely legal research conducted by examining library materials or secondary legal material while the problem approach is carried out using a legal approach and conceptual approach. The results of the study show that the legal consequences of fiduciary guarantee deeds, which have no legal force at all in carrying out executions and against objects of fiduciary guarantee do not give birth to material rights inherent in fiduciary guarantees. As a result of not registering a fiduciary deed, there is no legal protection at all for creditors.

Key words: Legal Protection, Registration of Fiduciary Guarantee Deed, Execution 


\section{PENDAHULUAN}

Jaminan fidusia sebagai salah satu lembaga jaminan sekarang ini turut serta memegang peranan penting dalam pembangunan ekonomi Indonesia, khususnya di bidang perbankan sebagai lembaga yang menyalurkan kredit dalam memenuhi kebutuhan modal. Karena perkembangan ekonomi dan perdagangan akan diikuti oleh perkembangan zaman, kebutuhan akan kredit dan pemberian fasilitas kredit ini memerlukan jaminan demi keamanan pemberian kredit tersebut. ${ }^{1}$

Pasal 1 dalam Undang-Undang Nomor 42 Tahun 1999 Tentang Jaminan Fidusia (UUJF), menyebutkan bahwa "Fidusia adalah pengalihan hak kepemilikan suatu benda atas dasar kepercayaan dengan ketentuan bahwa benda yang hak kepemilikannya dialihkan tersebut tetap dalam penguasaan pemilik benda”. Objek Jaminan fidusia sebelum berlakunya UUJF adalah benda bergerak yang terdiri dari benda dalam persediaan, benda dagangan, piutang, peralatan mesin, dan kendaraan bermotor. Namun sesudah berlakunya UUJF, maka objek Jaminan fidusia diberikan pengertian yang luas. Berdasarkan UUJF, objek Jaminan fidusia dibagi atas dua macam: ${ }^{2}$

1. Benda bergerak baik yang berujud maupun tidak berujud; dan

2. Benda tidak bergerak, khususnya bangunan yang tidak dibebani hak tanggungan.

UUJF menentukan agar benda yang menjadi obyek Jaminan fidusia pembebanannya dibuat dengan akta Notaris dan didaftarkan pada Kantor Pendaftaran Fidusia (KPF).

Pada umumnya dalam praktek perbankan perjanjian kredit dibuat dengan akta dibawah tangan karena demi efisiensi waktu dan mempermudah debitor yang akan mengambil kredit tanpa harus menunggu dalam pembuatan aktaotentik di hadapan Notarisdan untuk meminimalisasi biaya pembuatan akta dalam kredit, sedangkan bagi bank untuk penjaminan obyek yang dijaminkan dibuatlah akta penjaminan yang dibuat oleh Notaris apabila penjaminan dengan fidusia dan oleh Pejabat Pembuat Akta Tanah (untuk selanjutnya disebut PPAT) apabila penjaminan dengan Hak Tanggungan. ${ }^{3}$

${ }^{1}$ Sri Soedewi Masjchoen Sofwan, Hukum Jaminan Di Indonesia Pokok-Pokok Hukum Jaminan Dan Jaminan Perorangan, Liberty, Yogyakarta, 1980, hal. 1.

${ }^{2}$ Ibid, hal. 64

${ }^{3}$ Indah Antari Mutri, Perjanjian Kredir Dengan Jaminan fidusia Atas Kendaraan Bermotor Yang Dijual Pada Pihak Ktiga Pada PT. Bank Danamon (Persero) Tbk Unit DSP Pracimantoro Wonogiri, Tesis, Universitas Dipegoro, Semarang, 2010, hal. 2 
Proses Pembebanan Fidusia merupakan kegiatan terpenting dalam Jaminan fidusia yaitu dilakukannya penandatanganan akta Jaminan fidusia. Pembebanan Jaminan fidusia diatur dalam Pasal 4 sampai dengan Pasal 10 UUJF. Sifat Jaminan fidusia adalah perjanjian ikutan (accesoir) dari suatu perjanjian pokok yang menimbulkan kewajiban bagi para pihak untuk memenuhi suatu prestasi. Dan pembebanan Jaminan fidusia dibuat dengan akta Notaris dalam bahasa Indonesia ${ }^{4}$ Namun dalam praktek, sering terjadi bahwa perjanjian pokok yang menimbulkan kewajiban bagi para pihak untuk memenuhi suatu prestasi antara pihak pemberi fidusia dan penerima fidusia, tidak diikuti dengan pembebanan dalam akta Notaris yang merupakan kegiatan yang terpenting dalam pembebanan Jaminan fidusia. Salah satu syarat untuk mendaftarkan akta jaminan fidusia adalah bahwa akta itu harus dibuat dalam bentuk akta Notaris, sebab Kanwil Kementrian Hukum dan HAM, Seksi Pelayanan tidak menerima pendaftaran jaminan fidusia yang dibuat dengan akta dibawah tangan. Dengan demikian, akta Notaris adalah syarat mutlak pendaftaran jaminan fidusia. ${ }^{5}$

Dalam UUJF mengatur tentang pendaftaran Jaminan fidusia guna memberikan kepastian hukum kepada para pihak yang berkepentingan dan pendaftaran Fidusia memberikan hak yang didahulukan (preferen) kepada Penerima Fidusia terhadap kreditor lain. Namun dalam praktek, hal tersebut tidak sesuai harapan yang diinginkan para pembuat undang-undang (UUJF). Pendaftaran Jaminan fidusia diatur dalam Peraturan Pemerintah Nomor 21 Tahun 2015 Tentang Tentang Tata Cara Pendaftaran Jaminan Fidusia Dan Biaya Pembuatan Akta Jaminan Fidusia.

Tujuan dari pendaftaran Jaminan fidusia adalah $:^{6}$

1. Untuk memberikan kepastian hukum kepada para pihak yang berkepentingan;

2. Memberikan hak yang didahulukan (preferen) kepada penerima fidusia terhadap kreditor yang lain.

Melihat betapa pentingnya pendaftaran Jaminan fidusia guna memberikan kepastian hukum kepada para pihak yang berkepentingan, namun masih banyak pihak kreditor penerima fidusia yang tidak mendaftarkan akta jaminannya. ${ }^{7}$ Sebagai contoh, dalam praktek ditemukan fakta bahwa fidusia sebagai jaminan tidak dilaksanakan sesuai dengan aturan yang

\footnotetext{
${ }^{4}$ Salim HS, Perkembangan Hukum Jaminan Indonesia, Raja Grafindo Persada, Jakarta, 2011, hal. 65.

${ }^{5}$ Tan Kamelo, Hukum Jaminan fidusia (Suatu Kebutuhan Yang Di Dambakan), Alumni, Bandung, 2006, hal.. 216

${ }^{6}$ Salim HS, Op.Cit, hal. 82.

${ }^{7}$ Tan Kamelo, Loc.Cit..
} 
sudah diberlakukan semenjak tahun 1999, peraturan pelaksanaannya maupun peraturanperaturan lain yang mengatur mengenai pendaftaran jaminan fidusia. Diantaranya jaminan kredit pada KSP Artha Tani Mandiri dilakukan hanya dengan menambahkan jaminan fidusia untuk penyaluran kreditnya pada perjanjian kredit, namun dalam praktek jaminan fidusianya belum melaksanakan kewajiban dan aturan yang terdapat dalam UUJF. Jaminan fidusia tidak didaftarkan dan tidak dbuatkan akta Notaris. ${ }^{8}$

\section{RUMUSAN MASALAH}

1) Apa akibat-akibat hukum terhadap Jaminan fidusia yang tidak didaftarkan?

2) Apa perlindungan hukum kepada kreditor jika akta Fidusia tidak didaftarkan?

\section{METODE PENELITIAN}

Penelitian ini menggunakan metode penelitian hukum normatif yang dilakukan untuk mencari pemecahan masalah atas permasalahan hukum yang ada. Pendekatan penelitian yang digunakan adalah pendekatan undang-undang (statute approach) dan pendekatan konseptual (conceptual approach).

\section{PEMBAHASAN}

\section{Akibat-Akibat Hukum Jaminan Fidusia Yang Tidak Didaftarkan.}

Akta jamina fidusia merupakan perjanjian ikutan dari suatu perjanjian pokok, maka kegiatan terpenting dalam pembebanan perjanjian pokok ke dalam bentuk akta otentik adalah penandatanganan akta. Sesuai dengan UUJF, pembuatan akta jaminan fidusia wajib dibuat dengan akta notaris secara notariil akta artinya dibuat di hadapan notaris menggunakan bahasa Indonesia sebagaimana tersebut dalam Pasal 5 ayat (1) UUJF. Penegasan perjanjian jaminan fidusia dengan akta notaris dalam UUJF merupakan suatu norma yang memaksa (imperatif bukan fakultatif). Artinya apabila perjanjian jaminan fidusia dilakukan selain dalam bentuk akta notaris, secara yuridis perjanjian jaminan tersebut tidak pernah ada. Hal tersebut semakin jelas jika dikaitkan dengan proses terjadinya jaminan fidusia ketika

\footnotetext{
${ }^{8}$ Achmad Lukman Hakim, Tinjauan Yuridis Sosiologis Terhadap Pelaksanaan Perjanjian Kredit Dengan Jaminan Fidusia Tanpa Pendaftaran Oleh Kreditor (Studi d KSP ArthaTani Mandiri Banyuwangi), Docstoc, diakses dari http://www.docstoc.com/docs/ 95313334/ Tinjauan-Yuridis-Sosiologis TerhadapPelaksanaanPerjanjian-Kredit, diakses tanggal 22 Maret 2018.
} 
dilakukan pendaftaran pada Kantor Pendaftaran Fidusia (KPF) yang permohonannya harus dilengkapi dengan salinan akta notaris tentang pembebanan jaminan fidusia. ${ }^{9}$

Alasan mengapa UUJF menetapkan bentuk khusus (Akta Notaris) bagi perjanjian Jaminan fidusia adalah bahwa sebagaimana diatur dalam Pasal 1870 KUH Perdata yang menyatakan bahwa akta Notaris merupakan akta otentik memiliki kekuatan pembuktian sempurna. Mengingat bahwa objek Jaminan fidusia pada umumnya adalah barang bergerak yang tidak terdaftar, maka sudah sewajarnya bahwa bentuk akta otentiklah yang dianggap paling dapat menjamin kepastian hukum berkenaan dengan objek Jaminan fidusia.

Pendaftaran jaminan fidusia dibuat dengan akta notariil, konsekuensi jaminan fidusia yang tidak dibuat dengan akta notariil maka aktanya tidak dapat didaftarkan. Pendaftaran dilakukan setelah akta jaminan fidusia telah ditandatangani oleh para pihak pada Kantor Pendaftaran Fidusia (KPF) di tempat kedudukan pihak pemberi fidusia.

Pendaftaran suatu akta jaminan fidusia itu juga telah dinyatakan dalam suatu akta jaminan fidusia yang dibuat oleh notaris yang berbunyi demikian :

Pemberi fidusia dengan ini memberi kuasa kepada penerima fidusia yang menyatakan menerima kuasa dari pemberi fidusia untuk melaksanakan pendaftaran jaminan fidusia tersebut, untuk keperluan tersebut menghadap dihadapan pejabat atau instansi yang berwenang (termasuk kantor pendaftaran jaminan fidusia), memberikan keterangan, menandatangani surat/formulir, mendaftarkan jaminan fidusia atau objek jaminan fidusia tersebut dengan melampirkan pernyataan pendaftaran jaminan fidusia serta untuk mengajukan permohonan pendaftaran atas perubahan dalam hal terjadi perubahan atas data yang tercantum dalam sertifikat jaminan fidusia, selanjutnya menerima sertifikat jaminan fidusia dan/atau pernyataan perubahan sertifikat dokumen-dokumen lain yang bertalian dengan keperluan itu, membayar semua biaya dan menerima kwitansi segala pembayaran serta selanjutnya melakukan segala tindakan yang perlu dan berguna untuk melaksanakan ketentuan dari akta ini. ${ }^{10}$

Sebagai akibat dari tidak didaftarkan akta jaminan fidusia tersebut otomatis kekuatan pembuktian akta otentik telah terdegradasi dengan sendirinya sebagai akta dibawah tangan yang tidak memiliki kekuatan apapun dalam pembuktian jika terjadi wanprestasi karena yang menjadi titik tolak pembuktian jaminan fidusia adalah pada setifikat bukan pada aktanya. Nilai kesempurnaan akta notaris dalam perjanjian jaminan dengan fidusia ini, jika terjadi sengketa keperdataan antara para pihak otomatis dikesampingkan, sebab yang menjadi alat terkuat adalah suatu sertifikat yang di keluarkan oleh Kantor Pendaftaran Fidusia (KPF).

\footnotetext{
${ }^{9}$ Tan Kamelo, Op.Cit, hal. 195.

${ }^{10}$ Ibid, hal.21
} 
Akta notaris hanya sebagai syarat untuk pengeluaran sertifikat jaminan fidusia. hal tersebut ternyata dari syarat-syarat pengajuan pendaftaran jaminan fidusia pada Kantor Pendaftaran Jaminan Fidusia (KPF) yakni melampirkan salinan akta jaminan fidusia (akta notaris).

Oleh karena sebaiknya jika suatu akta jaminan fidusia yang telah selesai dilakukan pembebanannya berdasarkan perjanjian pokoknya didaftarkan pada Kantor Pendaftaran Fidusia (KPF). Sebab hanya dengan akta notariil saja belum cukup untuk membuktikan atau memperoleh hak agunan terhadap objek jaminan tersebut dan hak-hak yang diberikan UUJF kepada kreditor tidak diperloeh sesuai dengan prinsip jaminan fidusia menurut UUJF yaitu tiada pendaftaran tanpa pembebanan dan tidak menyebabkan akta notariil yang merupakan alat bukti sempurna yang secara lahiriah, formil dan materil adalah benar tidak terdegradasi sebagai akta dibawah tangan atau dengan kata lain tidak mengikat kedua belah pihak maupun pihak ketiga.

Grosse dari akta notaris mempunyai kekuatan eksekutorial yang sama dengan grosse putusan hakim. Dengan demikian tidak hanya tagihan berupa uang yang dapat dieksekusi berdasarkan grosse akta notaris, akan tetapi juga tuntutan, misalnya untuk menyerahkan barang bergerak. ${ }^{11}$ Namun pengeluaran grosse akta oleh notaris hanya terbatas pada pengeluaran grosse akta pengakuan utang sebagaimana yang telah dibatasi dalam Pasal 55 ayat (2) UUJN yang menyatakan bahwa "grosse akta pengakuan utang yang dibuat dihadapan notaris adalah salinan akta yang mempunyai kekuatan eksekutorial". Jadi akta notariil yang merupakan akta jaminan fidusia tanpa pendaftaran tidak dapat dilakukan eksekusi karena tidak mempunyai kekuatan eksekusi sebagaimana keputusan hakim yang telah memperoleh kekuatan hukum tetap.

Pendaftaran menurut UUJF merupakan momentum yang sangat tinggi nilainya dari lembaga jaminan fidusia, karena lahirnya hak agunan sebagaimana tersebut diatas yaitu pada saat terdaftarnya akta jaminan fidusia pada Kantor Pendaftaran Fidusia (KPF). Aspek hukum pendaftaran melahirkan hak mendahului sekaligus memberikan title eksekutorial bagi kepentingan penerima fidusia.

Tujuan dari pada pendaftaran jaminan fidusia adalah untuk memberikan hak yang didahulukan (preferen) kepada penerima Fidusia terhadap kreditor yang lain. Atau Dengan kata lain tujuan dari pendaftaran adalah untuk melahirkan hak kebendaan dan memenuhi asas

\footnotetext{
${ }^{11}$ Habib Adjie, Hukum Notaris Indonesia, Tafsir Tematik Terhadap UU No.30 Tahun 2004 Tentang Jabatan Notaris, Refika Aditama, Bandung, 2008, hal. 48.
} 
publisitas, juga untuk memperoleh kepastian hukum bagi para pihak dan pihak ketiga. ${ }^{12}$ Ini disebabkan Jaminan fidusia memberikan hak kepada penerima Fidusia untuk tetap menguasai bendanya yang menjadi objek Jaminan fidusia berdasarkan kepercayaan. Pada prinsipnya, sistim hukum jaminan terdiri dari jaminan kebendaan (zakelijkezekerheids) dan jaminan perorangan (personlijkezekerheids). ${ }^{13}$

Berdasarkan Pasal 1 angka 2 UUJF, jaminan fidusia merupakan jaminan kebendaan. Sebagai hak kebendaan, jaminan fidusia mempunyai sifat droit de suite dan droit de preference untuk mengambil pelunasan piutangnya atas hasil eksekusi benda jaminan. Dan hal tersebut tidak hapus walaupun terjadi kepailitan karena penerima fidusia merupakan kreditor separatis sebagaimana yang dicantumkan dalam Pasal 58 Undang-Undang Nomor 4 Tahun 1994 Tentang Kepailitan. ${ }^{14}$ Pembuktian apakah benda yang menjadi objek jamina fidusia sudah terdaftar atau belum dapat diketahui dari bukti surat kepemilikannya. Bukti kepemilikan benda yang menjadi objek jaminan fidusia dapat berupa dokumen dari benda itu, misalnya mobil dibuktikan dengan Surat Tanda Nomor Kendaraan (STNK) dan Buku Pemilik Kendaraan (BPKB). ${ }^{15}$

Namun dalam praktek sebagian besar penerima fidusia tidak mendaftarkan akta jaminan fidusia. Adapun alasan tidak didaftarkan akta jaminan fidusia :

1. Nominal penjaminan kecil, padahal biaya pendaftaran cukup besar dan karena itu tidak sesuai dengan asas manfaat;

2. Prosedur dan prosesnya lebih lama, dan hal ini erat kaitannya dengan birokrasi dan tempat.

Sebenarnya tidak ada ketentuan di dalam UUJF yang menyatakan bahwa jaminan fidusia yang tidak didaftarkan adalah tidak sah. Hanya saja untuk memberlakukan ketentuan yang ada di dalam undang-undang tersebut, maka haruslah dipenuhi syarat benda jaminan fidusia itu didaftarkan. Dari bunyi ketentuan tersebut dapat memberikan penafsiran yang berbeda, apakah jangka waktu 60 (enam puluh) hari tersebut merupakan jangka waktu pendaftaran jaminan fidusia ataukah pendaftaran bagi akta-akta jaminan fidusia yang telah ada sebelum didirikannya Kantor Pendaftaran Fidusia (KPF). Dalam UUJF selain daripada

\footnotetext{
${ }^{12}$ Tan Kamelo, Op.Cit, hal.129.

13 Hatta Isnaini Wahyu Utomo, "Hukum Jaminan", Bahan Ajar Mata Kuliah Hukum Jaminan, Universitas Yos Sudarso, 2017, hal. 18

${ }^{14}$ Ibid, hal. 29.

${ }^{15}$ Tan Kamelo, Op.Cit, hal. 129.
} 
jangka waktu tersebut tidak ada ketentuan yang mengatur mengenai kejelasan jangka waktu diharuskan untuk mendaftarkan akta jaminan fidusia tersebut. Jadi menurut penulis jangka waktu tersebut hanya berlaku bagi pendaftaran akta-akta jaminan fidusia yang telah ada sebelum didirikannya Kantor Pendaftaran Fidusia (KPF). Namun, sekalipun telah diberlakukan aturan tersebut dalam praktek masih terdapat perusahaan-perusahaan pembiayaan yang masih juga belum mendaftarkan akta jaminan fidusia sebagaimana telah disebutkan sebelumnya bahwa perjanjian jaminan fidusia itu sendiri hanya terbatas pada pembebanan akta notaris saja dan tidak melakukan pendaftaran sebagaimana yang diwajibkan oleh peraturan perundang-undangan tersebut.

Maka, akibat hukum dari jaminan fidusia yang tidak didaftarkan adalah tidak melahirkan perjanjian kebendaan bagi jaminan fidusia tersebut, sehingga karakter kebendaan seperti droit de suite (hak kebendaan senantiasa mengikuti bendanya ditangan siapa saja benda itu berada) dan hak prefensi tidak melekat pada kreditor pemberi jaminan fidusia; atau dengan kata lain jaminan fidusia bersifat persorangan (personlijkezekerheids). ${ }^{16}$

Berdasarkan ketentuan Pasal 15 ayat (2)UUJF, Sertifikat Jaminan Fidusia mempunyai kekuatan eksekutorial yang sama dengan putusan pengadilan yang telah memperoleh kekuatan hukum tetap. Berdasarkan titel eksekutorial ini penerima fidusia dapat langsung melaksanakan eksekusi melalui pelelangan umum atas objek jaminan fidusia tanpa melalui pengadilan. Ketentuan ini tercantum dalam Pasal 29 ayat (1) UUJF.

Pada asasnya lahirnya suatu sertifikat jaminan fidusia saat dilakukan pendaftaran pada Kantor Pendaftaran Fidusia (KPF) pada tiap-tiap ibukota propinsi yang berada dalam wilayah Departemen Hukum Dan Hak Asasi Manusia. Dalam sertifikat jaminan fidusia memuat irahirah "Demi Keadilan Berdasarkan Ketuhanan Yang Maha Esa". Adanya irah-irah tersebut apabila debitor melakukan wanprestasi maka kreditor penerima jaminan fidusia berhak untuk menjual barang jaminan tesebut. Adapun eksekusi dilakukan dengan cara :

a. Secara fiat eksekusi (dengan memakai titel eksekutorial), yang lewat suatu penetapan pengadilan.

b. Secara parate eksekusi. Parate executie adalah menjalankan sendiri atau mengambil sendiri apa yang menjadi haknya, dalam arti tanpa perantaraan hakim, yang ditujukan atas sesuatu barang jaminan untuk selanjutnya menjual sendiri barang tersebut.

\footnotetext{
${ }^{16}$.Tan Kamelo, Op.Cit, hal. 30.
} 
c. Dijual di bawah tangan oleh pihak kreditor sendiri.

d. Lewat gugatan biasa pengadilan.

Oleh karena itu jika suatu jaminan fidusia yang tidak dilakukan pendaftaran maka tidak memiliki sertifikat jaminan fidusia, yang artinya bahwa kreditor tidak dapat melakukan eksekusi terhadap objek jaminan melalui cara-cara yang ditentukan dalam UUJF sebagaimana tersebut diatas dan tidak mendapatkan pengamanan dari pihak kepolisian terhadap pelaksanaan eksekusiberdasarkan Peraturan Kapolri Nomor 8 Tahun 2011 Tentang Pengamanan Eksekusi Jaminan Fidusia.

\section{Perlindungan Hukum Dalam Hal Tidak Didaftarkannya Akta Jaminan Fidusia}

Jaminan fidusia adalah salah satu perlindungan hukum bagi keamanan kreditor yakni bagi suatu kepastian bahwa nasabah debitor akan melunasi pinjaman kredit. Perjanjian jaminan fidusia bukan suatu hak jaminan yang lahir karena undang-undang melainkan harus diperjanjikan terlebih dahulu antara bank dan nasabah debitor. Oleh karena itu, fungsi yuridis pengikatan jaminan fidusia lebih bersifat khusus jika dibandingkan dengan jaminan yang lahir berdasarkan Pasal 1131 KUH Perdata. Fungsi yuridis pengikatan benda jaminan fidusia dalam akta jaminan fidusia merupakan bagian yang tidak terpisahkan dengan dari perjanjian kredit.

Dengan fungsi yuridis jaminan fidusia yang dinyatakan dalam akta jaminan fidusia semakin meneguhkan kedudukan bank sebagai kedudukan preferen. Selain itu, kreditor penerima fidusia akan memperoleh keepastian terhadap pengembalian utang debitor. Fungsi yuridis itu juga akan mengurangi tingkat resiko bank dalam menjalankan usahanya sebagaimana yang dimaksud dalam undang-undang perbankan. ${ }^{17}$

Sejak diberlakukannya UUJF, dalam implementasinya masih terdapat pelanggaranpelanggaran hukum baik yang dilakukan oleh pihak kreditor (penerima fidusia) maupun oleh pihak debitor (pemberi fidusia). Pelanggaran-pelanggaran yang sering dilakukan oleh kreditor adalah sebagai berikut $:^{18}$

1. Kreditor tidak mendaftarkan obyek jaminan fidusia di Kantor Pendaftaran Fidusia (KPF).

\footnotetext{
${ }^{17}$ Ibid,.

${ }^{18}$ http://www.kumham-jogja.info/karya-ilmiah/37-karya-ilmiah-lainnya/183-pelanggaran-pelanggaranhukum-dalam-perjanjian-kredit-dengan-jaminan-fidusia, diaskes pada tanggal 18 Agustus 2018 pukul 10.01 WIB.
} 
2. Pendaftaran fidusia dilakukan setelah debitor wanprestasi.

3. Perjanjian kredit yang diikat dengan jaminan fidusia namun obyeknya bukan merupakan obyek jaminan fidusiaKreditor melakukan eksekusi terhadap obyek jaminan fidusia tidak sesuai ketentuan Pasal 29 UUJF.

Selain dilakukan oleh pihak kreditor, pelanggaran hukum terhadap ketentuan dalam UUJF juga dapat dilakukan oleh pihak debitor. Pelanggaran-pelanggaran yang sering dilakukan debitor adalah sebagai berikut $:^{19}$

1. Debitor menjaminkan lagi obyek jaminan fidusia (Fidusia ulang).

2. Pemberi fidusia (debitor) menggadaikan, mengalihkan atau menyewakan obyek

3. Debitor mengubah dan atau mengganti isi dari benda yang menjadi obyek jaminan.

Mengacu pada uraian tersebut diatas terlihat bahwa dalam praktek pemberian kredit dengan jaminan fidusia, ternyata masih banyak pelanggaran terhadap ketentuan-ketentuan dalam UUJF walaupun undang-undang tersebut telah berlaku lebih dari sepuluh tahun yang lalu. Oleh karena itu pelaksanaan jaminan fidusia dalam praktek masih memerlukan perhatian yang serius dari para penegak hukum khususnya para pembentuk undang-undang.

Jika ditinjau dari UUJF, apakah ada perlindungan hukum kepada pihak kreditor pada saat terjadi wanprestasi :

1. Bahwa pendaftaran ikatan jaminan atas benda tidak terdaftar sesungguhnya tidak cukup melindungi kepentingan kreditor terhadap pihak ketiga.

2. Dalam hal yang dijaminkan adalah benda persediaan atau inventory, maka kedudukan kreditor sangat lemah karena barang jaminan baik jumlah, perpindahan maupun kedudukan atau keberadaan barang tersebut sulit terdeteksi sehingga pemenuhan terhadap asas publisitas hanyalah pemenuhan dekoratif terhadap suatu aturan hukum. Keberlakuan dekoratif sesungguhnya memiliki potensi memunculkan masalah hukum baru yang tentu saja tidak dikehendaki oleh para pelaku bisnis dan para pembuat undang-undang di badan legislatif, khusus mengenai barang fidusia berupa inventori, barang komoditi agro telah diatur dengan undang-undang Nomor 9 tahun 2006 tentang Sistim Resi Gudang.

3. Dari sisi praktis, sistim pendaftaran fidusia dalam UUJF untuk sementara hanya bermanfaat bagi kreditor besar dengan jaminan yang mempunyai nilai besar saja. Debitor dari sektor Unit Usaha Kecil dan Menengah (UKM) sangat sulit memanfaatkan 
keberadaan undang-undang ini bagi pengembangan usaha mereka. Sifat universalitas aturan perundang-undangan menjadi sulit diterapkan karena hanya golongan tertentu khususnya pengusaha yang bermodal kuat saja yang dapat memanfaatkan keberadaan undang-undang ini.

4. Keberadaan Kantor Pendaftaran Fidusia (KPF) di ibu kota provinsi menyulitkan pelaksanaan pendaftaran fidusia, karena belum semua provinsi memiliki fasilitas transportasi yang memadai sehingga tidak memberikan manfaat dari segi kepraktisan. Terlebih bagi pemberi fidusia yang bertempat tinggal diluar wilayah Republik Indonesia. Dengan demikian peaksanaan pendaftaran akan menimbulkan biaya yang tidak sedikit dan waktu yang digunakan cukup lama. Ini tidak menunjang kondisi bisnis yang mempunyai filosofi waktu adalah uang (time is money).

5. Akta jaminan fidusia yang bernilai kecil dimanfaatkan oleh pengusaha menengah kebawah dan harus didaftarkan ternyata didalam kenyataan sebagian besar tidak didaftarkan ke Kantor Pendaftaran Fidusia (KPF). ${ }^{20}$

Uraian tersebut merupakan bukti kerancuan dalam pengaturan norma-norma dalam UUJF tidak didudukan pada asas hukum yang menjadi dasar pembentukan undang-undang guna mendukung eksistensi norma-norma tersebut dalam aturan perundang-undangan. Hal tersebut sebagai akibat dari peraturan tersebut dibuat secara tergesa-gesa dan tidak melewati kajian akademis yang memadai.

\section{PENUTUP}

\section{Kesimpulan}

Akibat hukum suatu jaminan fidusia yang tidak terdaftar pada kantor pendaftaran fidusia yaitu akta yang dibuat dihadapan pejabat umum notaris hanya dipandang sebagai suatu perjanjian biasa yang tidak memiliki kekuatan eksekutorial sama sekali, tidak melahirkan perjanjian kebendaan bagi jaminan fidusia tersebut, sehingga karakter kebendaan droit de suite dan droit deprefence tidak melekat pada objek jaminan fidusia sehingga proses eksekusi atas benda atau objek jaminan fidusia yang tidak didaftarkan tidak dapat dilakukan. Berdasarkan uraian pada pembahasan sebagaimana tersebut diatas penulis mengambil kesimpulan bahwa perlindungan hukum terhadap kreditor dalam hal tidak didaftarkannya hal. 38

\footnotetext{
${ }^{20}$ A.A. Andi Prajitno, Hukum Fidusia : Pasca Pendaftaran Secara Online, Putra Media Nusantara, 2018,
} 
akta jaminan fidusia dari UUJF tidak ada sama sekali karena menurut UUJF tiada suatu jaminan fidusia tanpa suatu pendaftaran.

\section{Saran}

Diperlukan adanya ketelitian bagi Notaris dalam membuat akta jaminan fidusia yang prosesnya meliputi pembuatan akta dan pendaftaran. Notaris sebagai pejabat yang mempunyai akses untuk mendaftarkan jaminan fidusia secara online harus mendaftarkan akta fidusia tepat waktu guna memenuhi asas publisitas. Kelalaian Notaris dalam melakukan pendaftaran jaminan fidusia dapat merugikan kreditur dan atas kelalaian tersebut Notaris dapat digugat untuk memberikan ganti rugi atas kerugian yang dialami kreditur.

\section{DAFTAR PUSTAKA}

A.A. Andi Prajitno, Hukum Fidusia : Pasca Pendaftaran Secara Online, Putra Media Nusantara, 2018

Habib Adjie, Hukum Notaris Indonesia, Tafsir Tematik Terhadap UU No.30 Tahun 2004 Tentang Jabatan Notaris, Refika Aditama, Bandung, 2008

Hatta Isnaini Wahyu Utomo, "Hukum Jaminan", Bahan Ajar Mata Kuliah Hukum Jaminan, Universitas Yos Sudarso, 2017

Indah Antari Mutri, Perjanjian Kredir Dengan Jaminan fidusia Atas Kendaraan Bermotor Yang Dijual Pada Pihak Ktiga Pada PT. Bank Danamon (Persero) Tbk Unit DSP Pracimantoro Wonogiri, Tesis, Universitas Dipegoro, Semarang, 2010

Salim HS, Perkembangan Hukum Jaminan Indonesia, Raja Grafindo Persada, Jakarta, 2011

Sri Soedewi Masjchoen Sofwan, Hukum Jaminan Di Indonesia Pokok-Pokok Hukum Jaminan Dan Jaminan Perorangan, Liberty, Yogyakarta, 1980

Tan Kamelo, Hukum Jaminan fidusia (Suatu Kebutuhan Yang Di Dambakan), Alumni, Bandung, 2006 